\title{
The Difficulties Facing by Student in Using Participle in Sentences
}

\author{
Zahari Amir Bin Ismani ${ }^{1}$, Siska Simamora ${ }^{2}$ \\ 1SEGi University, Selangor Darul Ehsan, Malaysia \\ 2SEAN Instiute, Sumatera Utara, Indonesia
}

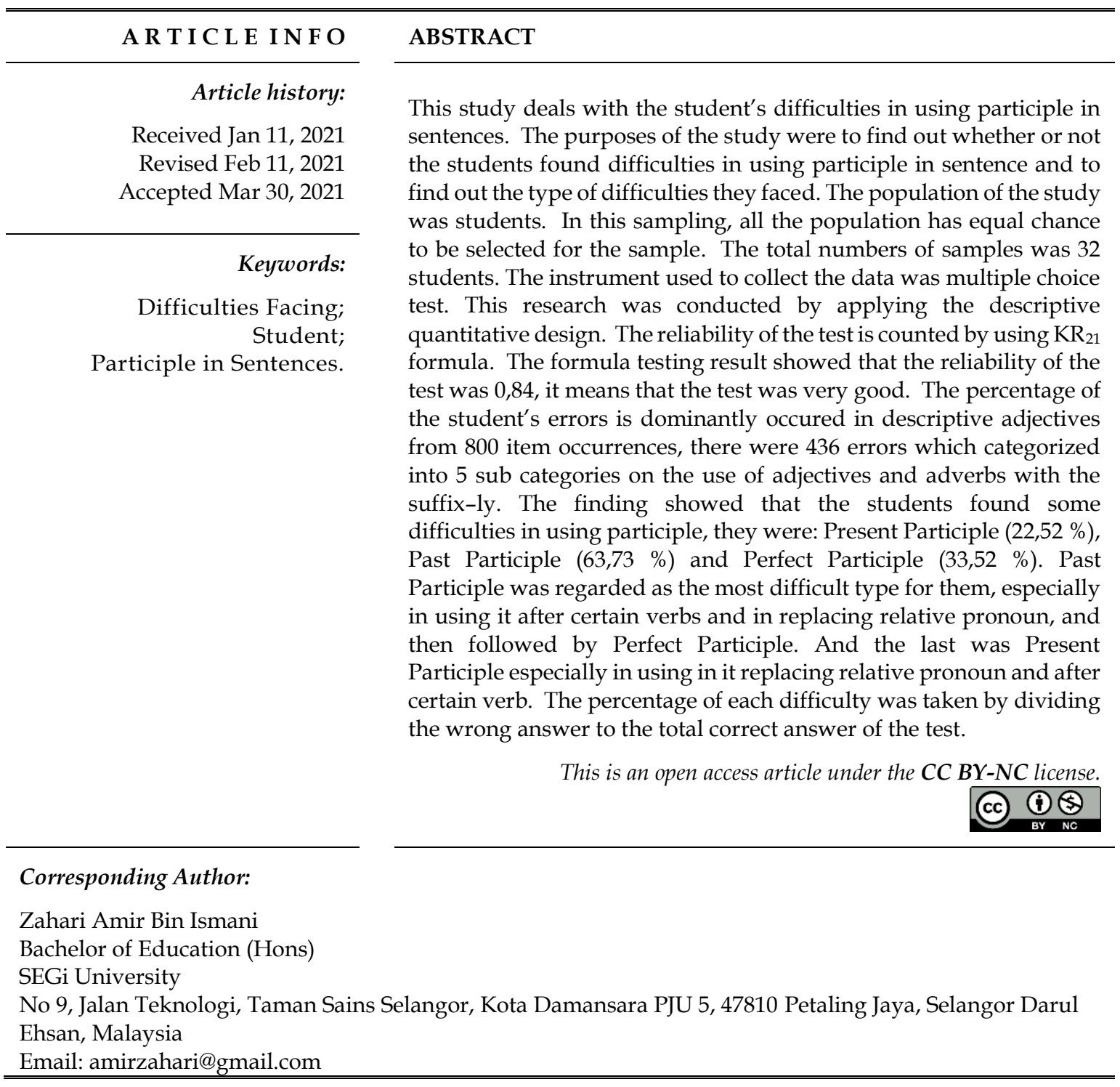

\section{INTRODUCTION}

Language is surely the most important tool of communication. People used language to express their ideas, thought, and feeling either in spoken or written mood. It means that language is used as primary means of communication in society (Dash \& Dash, 2007). 
Language plays an important role in human's life. He or she cannot survive without speaking a language, because it is a means of communication with one another to fulfill his or her needs (Fillmore, 1976). We can also say that language cannot separate from human beings. The important of language made many linguists attempt the definition of the word language and they can be found in dictionaries and in some text books (Makoni \& Mashiri, 2006). To be human is to use language, and to talk is to be a person.

Lewis Thomas (1974): "The gift of language is the single human traits that marks us all genetically, setting us apart from the rest of life. Language is like nest-building or hive-making, the universal and biologically specific activity of human beings. We engaged in it comunally, compulsively, and automatically. We cannot be human without it; if we were separated from it our minds would die as surely as bees lost from the hive." (Mario Finochiaro, 1960) "Language is a system of arbitrary, vocal symbols which permits all people in a given culture, or other people who have learned the system of that culture, to communicate or to interact."

Language itself develops highly. But how and when we talked is confusing. None of them has been solved (Ruiz, 1984). Most linguists think that this topic outside the realm of linguistic field. The writer here will not analyse the origins of language in detail because there is no real information about it (Larsen-Freeman, 2012).

Linguists believed that Adam wa blessed with two facilities for language, that is physical facility and non physical one (Saeidi \& Mazoochi, 2013). Physical facility includes speech organs and feeling and thought belong to non physical one. His language was also spoken by Eve and their children. Longer and longer they occupied many spaces in the world (Fishman, 1996). It means that the first language has branches in all parts of the world and from genetically related languages.

According to the theory of the origin of language, language of human beings consists of the mixture gestures and sounds. Meaning is involved in gestures. Linguists are more interested in studying the use of language than in speculating its origin (Hewes et al., 1973), (Hawhee, 2006).

It seems rather clearer that language began since men needed a greater degree of cooperation that required efficient communication. The ability of human beings to talk to use language in order to communicate with one another is so universal that we never think much about it. Every normal human being has acquired fellow human beings. But it doesnot mean that other living beings do not communicate with the other member of their species (Plutchik, 2001). Certainly, they do. And a few of them have communicate system that deserves to be called "language". Principally, language and culture cannot stay apart because it is the instrument used by society and it espresses or show the culture of that society. This relationship between language and culture takes place in the acquisition of foreign language for the way members of culture view the world is involved in it. The most important thing in learning a foreign language is the ability to comprehend and produce the foreign language in its spoken or written form.

As developing country, Indonesia has an International relationship to improve the area of politics, economics, industry and education. The language used most to connect this International relationship is English. Recently, English has become important as connection with the development of science and technology.

Because the importance of this language, English has been determined as the first foreign language and has become part of the curriculum. In the 1994 of junior high school curriculum, the study of English involves four languages skills, namely : listening, speaking, writing and reading.

Now, facing the information and globalization era many people are obliged to learn English as the global language. There are lots of facts to support the idea that learning English is crucial such as : 1) 400 million speakers of first language; 2) 700 million speakers of second or foreign language; 3) over $80 \%$ of the information stored in the world's computers is in English; 4) more than half the world's scientific journals are in English; and 5) it's the main language on the internet, films, songs, and so on (Porter Keith, 2003). 
In line of this, (Acha, 2003) said that English is one of the important things that we have to know because in this era of globalization there is much information written down in English. As Indonesian is one of the developing countries which treat English as a foreign language, as the consequence this English is taught to the students beginning from primary school up to university level. With this fact, it ishoped that the students realize English is an important language to be learnt. In addition, they can pass their exam, graduate from school, speak English, get better job, enter the college or university, etc.

Language is used for many purposes in our daily life. We pass on the news and information to others and get news and information from the others through language. It can be used to express our happiness and sorrow. In conclusion, it can be said that we use language to make contact with others.

English has become an important language in the world and it has been widely used in schools, governments and bussinesses. Therefore, it is one of the subjects to each for junior high school stdents, senior high school and universities.

Grammar is one important aspects in mastering the four language skills. For instance, (Lado, 1964) explained that: "The ability to use the structure/grammar, lexical items and their conventional representation in ordinary matters of fact in writing". This is clearly reflected in the curriculum of junior high school students, that the students are expected to be able to use sentences grammatically, they must know about the part of speech, tenses, gerund, participle, conditional sentences, subjunctive mood, and others. From all the parts of grammar, the writer is interested in discussing participle in this thesis. Participle is a verbal adjective i.e. words formed from a verb and doing the work of an adjective in describing noun. Participle can be divided into three types, there are : Present Participle, Past participle and Perfect Participle.

The writer found, in her experience while teaching the students at one of Test Guidance Program, that students face some difficulties in using participle (Wette, 2010). For example : "They sometimes find it difficult to differentiate present participle (V-ing) and gerund (V-ing). These two terms have the same form but their function is different. The difference can be seen from the sentence below : The crying child asked his mother to buy a toy., The children enjoyed swimming in the swimming pool.

In sentence above, we can find the same forms of $\mathrm{V}$-ing, they are : crying child and swimming pool. But of course these two forms have different functions, the first as adjective and the second as noun. Other kind of difficulties that they often make is to analyze the sentence using participle, such as : The students punished this morning will be reported to the Dean.

They often think that the predicate of the sentence is 'punished'. They just think that the verb has the function as predicate. This situation causes students often makes mistakes in forming sentence using participle.

\section{Research Method}

\section{RESEARCH METHODOLOGY}

This research was conducted by applying descriptive quantitative design. Quantitative research design are characterized by the assumption that human behavior can be explained by what may be termed social facts which can be investigated by methodologies that utilize the deductive logic at the natural sciences (Horne, 1994 ). It means that the study use numbers to analyze the data.

The study deals with single variable, the students difficulties. The result of the test was described as they in term of the existing condition without any interference of the researcher. The researcher was also presented by reporting them to the related literature mentioned in this study. 


\section{The population}

Population, in Encyclopedia of educational Evaluation by Scarvia B. Anderson it is said that, "A population is a set (or collection) of all elements possessing one or more attributes of interest." So, dealing with a research, of course, a population is the whole members of the object of the research.

Mohammad Ali also views that, "Keseluruhan objek penelitian sebagaimana diuraikan di atas, disebut dengan "populasi penelitian" atau universe." (1985). If we translate it into English we get all the object of the research said above is called population. And what he said above is that object being searched can be as human being, things, happenings or effects (1985).

Population is a group of people that you want to find out about by doing your research (Wallace, 1998). Furthermore, (Gray, 1987) states that: "Population is a group of the people or thing interesting to researcher, the group to which she or he would like the result of the study to be generalized.

Arikunto (1991) said that: "Population is the whole researched object. But since it is a large number to researched, the writer decides to involve two classes out of five that were randomly selected by using lottery technique so that all students have the same opportunity to follow the research and it is a representative sample".

\section{Sample}

The samples were obtained randomly, as (Gray, 1987) states that: "Random sampling is the best single way to obtain a representative sample". The writer limited the number of the students and selected only 32 as the samples. (Arikunto, 1992) states that : If the subjects in a large number, the samples can be drawn between $10-15 \%$ or $20-25 \%$ or more". In this sampling, all the population has equal chance to be selected for the sample.

\section{The Procedures of Collecting Data}

In collecting data, the writer conducted the following steps : (Grounlund, 1976) specifies the advantages of carrying out the objective tests (multiple choice items) are as follows : Multiple choice tests are effective for measuring knowledge of facts., Multiple choice is a quick objective scoring, easy, and consistent., It usually encourages pupils to develop a comprehensive knowledge of specific fact and the ability to make discrimination among them.

Groundlund also states that "multiple choice format" has two major advantages for course, such as : Such test is designed to measure the understanding and application for specific concept or principle., Because the students can answer a large number of such questioning in corporate in the test.

(Grounlund, 1977) states that : "The key to effective achievement testing is carefully planning". It provides greater assurances that one test will measure relevant learning outcomes. It means that before applying a test, there should be a good plan to prepare what to test. The data of this research was collected by using teacher made test. Students as observed were asked to answer the questions about participle in multiple choice tests consisted of 25 items.

The distribution of the test was :

$\begin{array}{ccc}\text { No. } & \text { Kinds of Participle } & \text { Items } \\ 1 . & \text { Present participle } & 10 \text { items } \\ 2 . & \text { Past participle } & 10 \text { items } \\ 3 . & \text { Perfect participle } & 5 \text { items }\end{array}$

\section{Administering the Test}

The procedure of administering the test was as follow: The seats of the students were arranged in such away in order to prevent them from cheating., The writer distributed the test and the answer sheet., The writer gave the instruction of how to answer the test., The allocated time was only 90 minutes., After the students had finishing doing the test, the writer collected the answer sheet and gave the score to their work. In scoring their work, the right answer was scored 0 and the wrong answer was not given score 1 . 


\section{Identifying the Difficulties were made by students}

After scoring the student's work, the writer identified their difficulties by grouping the student's mistakes/wrong answer into each kinds of participle and their sub category.

\section{The Reliability and Validity of the Test}

\section{Reliability of the Test}

A second important characteristic that all test should posses is reliability. A reliable test is consistent that is, if it repeated, student's score roughly the same as they did the first time they took the test.

Reliability is extent to which research can be repeated and show the same or similar research, stability or consistence of test result (Wallace, 1998). (Vockell, 1983) also said that : "Reliability is the degree of consistency with which a test (or alternate forms of the same test) will produce similar results on occasions when it theoretically should produce the same result". In other words the reliability of the test is the consistency of the scores for an individual who is talking the test several times.

While, reliability is the consistency of the test scores. (Lado, 1961) states that : Reliability is a general quality of stability of scores regardless of what the test measures". Thus, a test can not be valid unless it is also reliable, for an unreliable test can not measure the object of research. Whereas, (Wiersma, 1991) says that : "Reliability is the consistency of the instrument in measuring whatever it measures". Reliability coefficient can take on values of $-1,0$ to 1,0 inclusive.

Reliability is a necessary characteristic of any good test to be valid at all, a test must first a reliable measuring instrument. (Walden and Frankel, 1991) define reliability refers to the consistency of information obtained.

The definition above implies that more reliable the test is more confident we can have the scores obtained from the administration of the test. Therefore, if the test scores of the students are not fluctuate too much, then the test is called reliable.

In this study, KR 21 formula is applied to obtain the reliability of multiple choice test. The reason of choosing KR 21 is it does not need to do items analysis taking a long process.

To get the reliability of the test, the following formula is used :

$$
\mathrm{KR}-21=\frac{k}{k-1}\left[1-\frac{M(k-M)}{k(S D)^{2}}\right]
$$

Where :

$$
\begin{aligned}
& \mathrm{k}=\text { The number of the items in the test } \\
& \mathrm{M}=\text { The mean of the test scores } \\
& \mathrm{SD}=\text { The standard deviation of the test }
\end{aligned}
$$

To get the reliability of the test, first, the mean and the standard deviation were counted by using the following formula :

$$
M=\frac{\sum f x}{N}
$$

Where :

$$
\begin{aligned}
& \mathrm{M}=\text { Mean } \\
& \mathrm{f}=\text { Frequency } \\
& \mathrm{N}=\text { The number of the scores } \\
& \mathrm{X}=\text { The raw scores } \\
& S=i \sqrt{\frac{\sum f d}{N}}-\left(\frac{\sum f d}{N}\right)
\end{aligned}
$$

Where:

$$
\mathrm{i}=\text { Interval }
$$




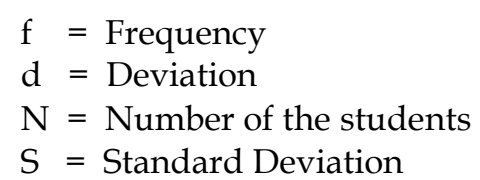

Thus, a complete lack of reliability would be indicated by a coefficient of 0,00 and a perfect positive reliability would be indicated by a coefficient of 1,00 . the psychometrics said that the reliability of the test may not be less than 0,70 .

\section{Validity of the Test}

The most important characteristics of any test should posses is that validity. The usual definition of a valid test is to measure hat it is supposed to measure. (Like L. R, Gay, 1991) says that : "Validity is the degree to which a test is measure what it supposed to measure".

Mesick (1988) for example describes validity as : "An integrated evaluative judgment of the degree to which empirical evidence and theoretical rationales support the adequacy and appropriateness of inferences and actions based on teat scores". Validity in research, this terms refers to whether or not the result of the measure men of experience really show what they claim to show (Vockell, 1983). In other words, the validity of a test refers to the concept of whether the test is measure what it is design to measure.

Validity refers to the appropriateness of a given test or of its component part as a measurement of what is supposed to measure and nothing else. A test is said to be valid if it measures what intended to measure (Tinambunan, 1988 ), as he quoted from Grounlund's.

The validity of a test represents the extent to which a test measures what its purpose to measure. According to (Borg and Gall, 1983) : “Validity is the degree to which a test measures what it purports to measure". "In simple words, does the test really measure the characteristics that it is being used to measure?" (Tuck man, 1978). (Wren, 1990) states that, "The concept of validity is the test measure what it is intended to measure?"

A good test should be both valid and reliable. Validity refers to whether or not a test measures what it purpose to measure. Reliability is a general quality of stability of scores regardless of what the test measures. Thus, a test cannot be valid unless it is also reliable, for an unreliable test does not measure what it should measure. One of the targets to know a good test is to consider its validity because it is important to prepare a test. In relation to the validity, (Walden and Frankel, 1991) states that validity refers to the extend to which an instrument gives us information we want. Furthermore, (Stanley, 1981) gives his definitions as follows "Validity as the degree to which measuring instruments actually serves the purpose for which it is used".

In line with the definitions above, it can be concluded that a good test is called valid if the test can measure, for instance, the ability of a student in mastering one material after it has been taught.

Without the standards for validity, tests can be misused and may actually have deleterious effects on the person being tested. To establish the validity of the test administered, the material was taken from the second year student material based on the English course design.

In this research, the test given to the sample class is based on the English KTSP of the 2011 Junior High School Curriculum. The test was to determinate the extent to which the students find some difficulties in using participle in sentences. To find out the validity, the writer applied the formula recommended by Arikunto as the following :

$$
P=\frac{B}{J S}
$$

Where :

$\mathrm{P}=$ index of difficulty

$\mathrm{B}=$ right answer

$\mathrm{JS}=$ number of items 
To test the validity, Arikunto correlation formula was applied and recommended that the value and the formula of validity test was as follow :

$$
\begin{aligned}
& 0,00-0,30=\text { difficult } \\
& 0,31-0,70=\text { fair } \\
& 0,71-1,00=\text { easy }
\end{aligned}
$$

\section{The Technique of Analyzing Data}

After the data had been collected, it was analyzed in the following steps: The writer identify all the student's difficulties., The writer analysed the types and the percentage of the difficulties., To find out the percentage of the difficulties, the writer divided the number of wrong answer by the total number of the correct answer and multiplied its result by one hundred percent.

\section{RESULT AND DISCUSSION}

The Result of the Test

As it has been mentioned in the previous chapter, the data was obtained by test. There were 25 items of test. The writer listed the score as can be seen in table 1.

\begin{tabular}{|c|c|c|}
\hline No. & Student's Reg. Number & Scores \\
\hline 1 & 2 & 3 \\
\hline 1 & 001 & 8 \\
\hline 2 & 002 & 11 \\
\hline 3 & 003 & 9 \\
\hline 4 & 004 & 13 \\
\hline 5 & 005 & 9 \\
\hline 6 & 006 & 12 \\
\hline 7 & 007 & 10 \\
\hline 8 & 008 & 11 \\
\hline 9 & 009 & 14 \\
\hline 10 & 010 & 10 \\
\hline 11 & 011 & 10 \\
\hline 12 & 012 & 13 \\
\hline 13 & 013 & 18 \\
\hline 14 & 014 & 8 \\
\hline 15 & 015 & 10 \\
\hline 16 & 016 & 7 \\
\hline 17 & 017 & 11 \\
\hline 18 & 018 & 9 \\
\hline 19 & 019 & 16 \\
\hline 20 & 020 & 11 \\
\hline 21 & 021 & 10 \\
\hline 22 & 022 & 13 \\
\hline 23 & 023 & 10 \\
\hline 24 & 024 & 9 \\
\hline 25 & 025 & 7 \\
\hline 26 & 026 & 12 \\
\hline 27 & 027 & 13 \\
\hline 28 & 028 & 19 \\
\hline
\end{tabular}

Table 1

The Score of Students in Using Participle in Sentences 


\begin{tabular}{ccc}
\hline No. & Student's Reg. Number & Scores \\
\hline $\mathbf{1}$ & $\mathbf{2}$ & $\mathbf{3}$ \\
29 & 029 & 23 \\
30 & 030 & 10 \\
31 & 031 & 9 \\
32 & 032 & 9 \\
& JUMLAH & $\mathbf{3 6 4}$ \\
& RATA-RATA & $\mathbf{1 1 . 3 8}$ \\
\hline
\end{tabular}

\section{The Reliability of the Test}

The $\mathrm{KR}_{21}$ formula was applied to test the reliability. To work on the formula, it is must concern on number of class $(\mathrm{K})$, class interval, the mean, and the standard deviation (SD).

Number of Class

In which :

$$
K=1+3,3 \log n
$$

$$
\mathrm{N}=\text { number of samples }=32
$$

So :

$$
\begin{aligned}
\mathrm{K} & =1+3,3 \log 32 \\
& =1+4,9669 \\
& =5,9669 \\
& =6 \text { (rounded) }
\end{aligned}
$$

Class Interval (Ci)

Where :

$$
\text { Class interval }(\mathrm{Ci})=\frac{\mathrm{R}}{\mathrm{K}}
$$

$$
\begin{aligned}
& \mathrm{R}=\text { range } \\
& \mathrm{K}=\text { number of class } \\
& \mathrm{Ci}=\frac{23-7}{6}=2,67
\end{aligned}
$$

The Data Tabulation (S)

Table 2

The Tabulation of the Data

\begin{tabular}{cccccc}
\hline No. & Class interval & f & d & fd & $\mathbf{f d}^{\mathbf{2}}$ \\
\hline 1 & 7 & 2 & 5 & 10 & 100 \\
2 & 8 & 2 & 4 & 8 & 64 \\
3 & 9 & 6 & 3 & 18 & 324 \\
4 & 10 & 7 & 2 & 14 & 196 \\
5 & 11 & 4 & 1 & 4 & 16 \\
6 & 12 & 2 & 0 & 0 & 0 \\
7 & 13 & 4 & -1 & -1 & 1 \\
8 & 14 & 1 & -2 & -2 & 4 \\
9 & 16 & 1 & -3 & -3 & 9 \\
10 & 18 & 1 & -4 & -4 & 16 \\
11 & 19 & 1 & -5 & -5 & 25 \\
12 & 23 & 1 & -6 & -6 & 36 \\
& Total & 32 & & 33 & $\mathbf{1 0 8 9}$ \\
\hline
\end{tabular}

The Mean

$$
M=M+\frac{f d}{N} x C i
$$

Where : 


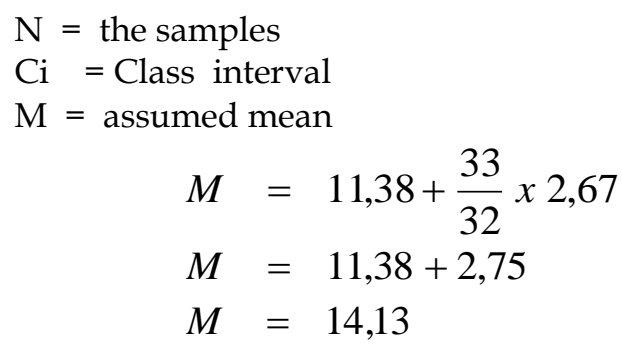

The Standard Deviation

$$
\begin{aligned}
& S=C i \sqrt{\frac{\left(\sum f d^{2}\right)}{n}-\left(\frac{f d}{n}\right)^{2}} \\
& S=1 \sqrt{\frac{1089}{32}-\left(\frac{33}{32}\right)^{2}} \\
& S=\sqrt{34,03-1,06} \\
& S=\sqrt{32,97} \\
& S=5,74
\end{aligned}
$$

The Testing of reliability

The Reliability of the test is as the following :

$$
\begin{aligned}
\mathrm{KR}-21 & =\frac{k}{k-1}\left[1-\frac{M(k-M)}{k(S D)^{2}}\right] \\
& =\frac{25}{25-1}\left[1-\frac{14,13(25-14,13)}{25(5,74)^{2}}\right] \\
& =1,04\left[1-\frac{153,59}{824,25}\right] \\
& =1,04[1-0,186] \\
& =1,04 \times 0,81 \\
& =0,84
\end{aligned}
$$

The formula testing result shows the value of reliability is 0,84 . Thus, the test was very good.

\section{The Testing of the Validity}

To test the validity, Arikunto correlation formula was applied. Arikunto (1992:212) recommends that the value and the formula of the test validity is as the following :

$$
\begin{aligned}
& 0,00-0,30=\text { difficult } \\
& 0,31-0,70=\text { fair } \\
& 0,71-1,00=\text { easy }
\end{aligned}
$$

The formula is : $P=\frac{B}{J S}$

Where : 


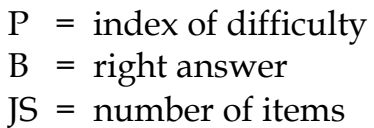

Table 3.

Test The Validity

\begin{tabular}{|c|c|c|c|c|}
\hline $\begin{array}{l}\text { Sample's } \\
\text { Number }\end{array}$ & $\begin{array}{c}\text { Right } \\
\text { Answer }\end{array}$ & $\begin{array}{c}\text { Number of } \\
\text { Items }\end{array}$ & $\begin{array}{c}\text { Index of } \\
\text { Difficulty }\end{array}$ & Value \\
\hline & B & JS & $\mathbf{P}$ & \\
\hline 1 & 2 & 3 & 4 & 5 \\
\hline 001 & 8 & 25 & 0.32 & FAIR \\
\hline 002 & 11 & 25 & 0.44 & FAIR \\
\hline 003 & 9 & 25 & 0.36 & FAIR \\
\hline 004 & 13 & 25 & 0.52 & FAIR \\
\hline 005 & 9 & 25 & 0.36 & FAIR \\
\hline 006 & 12 & 25 & 0.48 & FAIR \\
\hline 007 & 10 & 25 & 0.4 & FAIR \\
\hline 008 & 11 & 25 & 0.44 & FAIR \\
\hline 009 & 14 & 25 & 0.56 & FAIR \\
\hline 010 & 10 & 25 & 0.4 & FAIR \\
\hline 011 & 10 & 25 & 0.4 & FAIR \\
\hline 012 & 13 & 25 & 0.52 & FAIR \\
\hline 013 & 18 & 25 & 0.72 & EASY \\
\hline 014 & 8 & 25 & 0.32 & FAIR \\
\hline 015 & 10 & 25 & 0.4 & FAIR \\
\hline 016 & 7 & 25 & 0.28 & DIFFICULT \\
\hline 017 & 11 & 25 & 0.44 & FAIR \\
\hline 018 & 9 & 25 & 0.36 & FAIR \\
\hline 019 & 16 & 25 & 0.64 & FAIR \\
\hline 020 & 11 & 25 & 0.44 & FAIR \\
\hline 021 & 10 & 25 & 0.4 & FAIR \\
\hline 022 & 13 & 25 & 0.52 & FAIR \\
\hline 023 & 10 & 25 & 0.4 & FAIR \\
\hline 024 & 9 & 25 & 0.36 & FAIR \\
\hline 025 & 7 & 25 & 0.28 & DIFFICULT \\
\hline 026 & 12 & 25 & 0.48 & FAIR \\
\hline 027 & 13 & 25 & 0.52 & FAIR \\
\hline 028 & 19 & 25 & 0.76 & EASY \\
\hline 029 & 23 & 25 & 0.92 & EASY \\
\hline 030 & 10 & 25 & 0.4 & FAIR \\
\hline 031 & 9 & 25 & 0.36 & FAIR \\
\hline 032 & 9 & 25 & 0.36 & FAIR \\
\hline
\end{tabular}

Note :

$\begin{array}{ll}\text { Easy } & =3 \text { items } \\ \text { Fair } & =27 \text { items } \\ \text { Difficult } & =2 \text { items }\end{array}$

Total $=32$ items

The Distribution of Student's Difficulties

The test consisted of 25 items to cover up the majority of the difficulties in using participle in sentences. The students found the difficulties in all types of participle, namely present participle, past participle, and perfect participle.

In this study, the types of difficulties were taken from the usages of each participle. They were : 
1) Present Participle
a) As adjective
b) To form continuous form
c) After verbs of sensations
d) To replace relative pronoun
e) After certain verbs
f) To replace subject clause

2) Past Participle
a) As adjective
b) To form passive voice
c) To replace relative pronoun
d) To replace subject
e) After verbs of sensations
f) After certain verbs

3) Perfect Participle
a) Present Perfect Participle
b) Past Perfect Participle

Table 4.

Number of Student's Difficulties in Type of Using Present Participle

\begin{tabular}{|c|c|c|c|c|c|c|c|c|c|c|c|}
\hline Students & 1 & 2 & 3 & 4 & 5 & 6 & 7 & 8 & 9 & 10 & TOTAL \\
\hline 1 & 2 & 3 & 4 & 5 & 6 & 7 & 8 & 9 & 10 & 11 & 12 \\
\hline 1 & & & & & & & 1 & 1 & & & 2 \\
\hline 2 & & & & & & & 1 & 1 & 1 & & 3 \\
\hline 3 & & & & & & & & & 1 & & 1 \\
\hline 4 & & & & & & & 1 & 1 & 1 & 1 & 4 \\
\hline 5 & & & & & & & & 1 & 1 & & 2 \\
\hline 6 & & & & & & & 1 & 1 & & & 2 \\
\hline 7 & & & & & & & 1 & 1 & & 1 & 3 \\
\hline 8 & & & & & & & & 1 & & 1 & 2 \\
\hline 9 & & & & & & & 1 & 1 & 1 & 1 & 4 \\
\hline 10 & & & & & & & 1 & 1 & & 1 & 3 \\
\hline 11 & & & & & & & & 1 & & 1 & 2 \\
\hline 12 & & & & & & & 1 & & 1 & & 2 \\
\hline 13 & & & & & & & 1 & & 1 & & 2 \\
\hline 14 & & & & & & & 1 & & 1 & 1 & 3 \\
\hline 15 & & & & & & & 1 & & 1 & & 2 \\
\hline 16 & & & & & & 1 & 1 & 1 & 1 & 1 & 5 \\
\hline 17 & & & & & & & & 1 & 1 & & 2 \\
\hline 18 & & & & & & 1 & 1 & 1 & 1 & & 4 \\
\hline 19 & & & & & & 1 & & 1 & 1 & 1 & 4 \\
\hline 20 & & & & & & & & & & 1 & 1 \\
\hline 21 & & & & & & 1 & 1 & & & & 2 \\
\hline 22 & & & & & & & 1 & 1 & & 1 & 3 \\
\hline 23 & & & & & & & 1 & 1 & & 1 & 3 \\
\hline 24 & & & & & & & & 1 & & 1 & 2 \\
\hline 25 & & & & & & & 1 & 1 & & 1 & 3 \\
\hline 26 & & & & & & & & 1 & & 1 & 2 \\
\hline 27 & & & & & & & & 1 & & 1 & 2 \\
\hline 28 & & & & & & & 1 & 1 & & & 2 \\
\hline 29 & & & & & & & 1 & 1 & & & 2 \\
\hline 30 & & & & & & & & 1 & 1 & 1 & 3 \\
\hline 31 & & & & & & 1 & 1 & 1 & 1 & & 4 \\
\hline
\end{tabular}




\begin{tabular}{cccccccccccc}
\hline Students & $\mathbf{1}$ & $\mathbf{2}$ & $\mathbf{3}$ & $\mathbf{4}$ & $\mathbf{5}$ & $\mathbf{6}$ & $\mathbf{7}$ & $\mathbf{8}$ & $\mathbf{9}$ & $\mathbf{1 0}$ & TOTAL \\
\hline 1 & 2 & 3 & 4 & 5 & 6 & 7 & 8 & 9 & 10 & 11 & 12 \\
\hline 32 & & & & & & & & & & 1 & 1 \\
Total & 0 & 0 & 0 & 0 & 0 & 5 & 20 & 24 & 15 & 18 & 82 \\
Proportion & 0 & 0 & 0 & 0 & 0 & 1.37 & 5.49 & 6.59 & 4.12 & 4.95 & 22.5275 \\
\hline
\end{tabular}

Table 4 shows the student's difficulties in using Present Participle in sentences. There were 82 out of 364 correct sentences $(22,52 \%)$. This implies that the students find some difficulties in using Present Participle.

Table 5

Number of Student's Difficulties in Type of Using Past Participle

\begin{tabular}{|c|c|c|c|c|c|c|c|c|c|c|c|}
\hline Students & 11 & 12 & 13 & 14 & 15 & 16 & 17 & 18 & 19 & 20 & TOTAL \\
\hline 1 & 2 & 3 & 4 & 5 & 6 & 7 & 8 & 9 & 10 & 11 & 12 \\
\hline 1 & 1 & 1 & 1 & 1 & 1 & 1 & 1 & 1 & 1 & 1 & 10 \\
\hline 2 & 1 & 1 & & & & 1 & 1 & 1 & 1 & & 6 \\
\hline 3 & 1 & 1 & 1 & 1 & 1 & 1 & 1 & 1 & 1 & 1 & 10 \\
\hline 4 & & 1 & & & 1 & & & 1 & & 1 & 4 \\
\hline 5 & 1 & 1 & 1 & 1 & 1 & 1 & 1 & 1 & 1 & 1 & 10 \\
\hline 6 & 1 & 1 & 1 & 1 & 1 & 1 & 1 & & & 1 & 8 \\
\hline 7 & 1 & 1 & 1 & 1 & 1 & 1 & 1 & 1 & & 1 & 9 \\
\hline 8 & 1 & 1 & 1 & 1 & 1 & 1 & 1 & & & 1 & 8 \\
\hline 9 & 1 & & & & & & 1 & & & 1 & 3 \\
\hline 10 & 1 & 1 & 1 & 1 & 1 & 1 & 1 & & 1 & & 8 \\
\hline 11 & 1 & 1 & 1 & 1 & 1 & 1 & 1 & 1 & 1 & & 9 \\
\hline 12 & 1 & 1 & & 1 & & 1 & & & 1 & 1 & 6 \\
\hline 13 & 1 & 1 & & & & & & & & & 2 \\
\hline 14 & 1 & 1 & 1 & 1 & 1 & 1 & 1 & 1 & 1 & 1 & 10 \\
\hline 15 & 1 & 1 & & 1 & 1 & 1 & 1 & 1 & 1 & 1 & 9 \\
\hline 16 & 1 & 1 & & 1 & 1 & & 1 & 1 & 1 & 1 & 8 \\
\hline 17 & 1 & 1 & & 1 & 1 & 1 & 1 & 1 & 1 & 1 & 9 \\
\hline 18 & 1 & 1 & 1 & 1 & 1 & 1 & 1 & 1 & 1 & & 9 \\
\hline 19 & & 1 & 1 & & & & 1 & 1 & 1 & & 5 \\
\hline 20 & 1 & 1 & & 1 & 1 & 1 & 1 & & 1 & 1 & 8 \\
\hline 21 & 1 & & & 1 & 1 & 1 & 1 & 1 & 1 & 1 & 8 \\
\hline 22 & 1 & & & & 1 & & 1 & 1 & & 1 & 5 \\
\hline 23 & 1 & & & 1 & 1 & 1 & 1 & 1 & 1 & 1 & 8 \\
\hline 24 & 1 & 1 & 1 & 1 & & 1 & 1 & 1 & 1 & 1 & 9 \\
\hline 25 & 1 & 1 & 1 & 1 & 1 & 1 & 1 & 1 & 1 & 1 & 10 \\
\hline 26 & & 1 & 1 & 1 & & & & 1 & 1 & 1 & 6 \\
\hline 27 & 1 & & & 1 & & & & 1 & 1 & 1 & 5 \\
\hline 28 & 1 & & & & & & & 1 & 1 & & 3 \\
\hline 29 & & & & & & & & & & & 0 \\
\hline 30 & 1 & 1 & 1 & 1 & & 1 & 1 & 1 & 1 & & 8 \\
\hline 31 & 1 & 1 & 1 & 1 & & 1 & 1 & 1 & 1 & 1 & 9 \\
\hline 32 & 1 & 1 & 1 & 1 & 1 & 1 & 1 & 1 & 1 & 1 & 10 \\
\hline Total & 28 & 25 & 17 & 24 & 20 & 22 & 25 & 24 & 24 & 23 & 232 \\
\hline Proportion & 7.69 & 6.87 & 4.67 & 6.59 & 5.49 & 6.04 & 6.87 & 6.59 & 6.59 & 6.32 & 63.7363 \\
\hline
\end{tabular}

Table 5 above presents the student's difficulties in the type of using Past Participle (Verb-3) in sentences. There were 232 out of 266 correct answer $(63,74 \%)$. 
Table 6.

Number of Student's Difficulties in Type of Using Perfect Participle

\begin{tabular}{|c|c|c|c|c|c|c|}
\hline Students & 21 & 22 & 23 & 24 & 25 & TOTAL \\
\hline 1 & 2 & 3 & 4 & 5 & 6 & 12 \\
\hline 1 & 1 & 1 & 1 & 1 & 1 & 5 \\
\hline 2 & 1 & 1 & 1 & 1 & 1 & 5 \\
\hline 3 & 1 & 1 & 1 & 1 & 1 & 5 \\
\hline 4 & 1 & 1 & & 1 & 1 & 4 \\
\hline 5 & 1 & & 1 & 1 & 1 & 4 \\
\hline 6 & 1 & & 1 & & 1 & 3 \\
\hline 7 & & 1 & 1 & & 1 & 3 \\
\hline 8 & & 1 & 1 & 1 & 1 & 4 \\
\hline 9 & 1 & 1 & 1 & & 1 & 4 \\
\hline 10 & & 1 & 1 & 1 & 1 & 4 \\
\hline 11 & & 1 & 1 & 1 & 1 & 4 \\
\hline 12 & 1 & & 1 & 1 & 1 & 4 \\
\hline 13 & 1 & & 1 & & 1 & 3 \\
\hline 14 & 1 & 1 & 1 & & 1 & 4 \\
\hline 15 & 1 & & 1 & 1 & 1 & 4 \\
\hline 16 & 1 & 1 & 1 & 1 & 1 & 5 \\
\hline 17 & 1 & & 1 & 1 & & 3 \\
\hline 18 & 1 & & 1 & 1 & & 3 \\
\hline 19 & & & & & & 0 \\
\hline 20 & 1 & 1 & 1 & 1 & 1 & 5 \\
\hline 21 & 1 & 1 & 1 & 1 & 1 & 5 \\
\hline 22 & 1 & 1 & 1 & & 1 & 4 \\
\hline 23 & 1 & 1 & 1 & & 1 & 4 \\
\hline 24 & 1 & 1 & 1 & 1 & 1 & 5 \\
\hline 25 & 1 & 1 & 1 & 1 & 1 & 5 \\
\hline 26 & 1 & 1 & 1 & 1 & 1 & 5 \\
\hline 27 & 1 & 1 & 1 & 1 & 1 & 5 \\
\hline 28 & & & & 1 & & 1 \\
\hline 29 & & & & & & 0 \\
\hline 30 & 1 & 1 & & 1 & 1 & 4 \\
\hline 31 & & 1 & 1 & 1 & & 3 \\
\hline 32 & 1 & 1 & 1 & 1 & 1 & 5 \\
\hline Total & 24 & 22 & 27 & 23 & 26 & 122 \\
\hline Proportion & 6.593 & 6.044 & 7.418 & 6.319 & 7.143 & 33.5164835 \\
\hline
\end{tabular}

The table above (table 6) shows the student's difficulties in the type of using Perfect Participle in sentences. There were 122 out of 266 correct answer $(33,52 \%)$. This implies that students have difficulties in using Perfect Participle in sentences.

The Judgment of Students of Junior High School

The data analysis results decided that the samples found difficulties in doing the test. Table 7 shows the comparison percentage among the types of using Present Participle, and Perfect Participle.

Table 7.

The Comparison Percentage among the Types in Using Present Participle, Past Participle and Perfect Participle

\begin{tabular}{cccccc}
\hline \multicolumn{2}{c}{ Present Participle } & \multicolumn{2}{c}{ Past Participle } & \multicolumn{2}{c}{ Perfect Participle } \\
\hline Number & Percentage & Number & Percentage & Number & Percentage \\
82 & $22,52 \%$ & 232 & $63,73 \%$ & 122 & $33,52 \%$ \\
\hline
\end{tabular}


The table shows that the most difficult types of participle faced by the students was Past Participle, followed by Present Participle and Perfect Participle.

\section{CONCLUSION}

After analysing the data presented in the previous chapters, the writer can conclude that: The third year students of Junior High School in Indonesia found difficulties in using Participle in sentences. The percentage of the difficulties from each type of participle was : Present Participle: 22,52 \%, Past Participle: 63,73 \%, Perfect Participle: 33,52 \%., The most difficult type for the students was Past Participle. They found some difficulties in using Past Participle after certain verbs and in replacing relative pronoun, then in using Perfect Participle. And the last was Present Participle in replacing relative pronoun and after verbs of sensations. The students find it difficult to use Present Participle and Past Participle in replacing relative pronoun.

\section{References}

Acha. Kompas. 2003. Jakarta. October 17.

Allen, W. Stan nard. 1987. Living English Structure. Orient-New York : Long man Limited, Madras.

Ali, Muhammad. 1985. Penelitian Kependidikan, Prosedur dan Strategi. Bandung : Angkasa.

Arikunto, S, Dr. 1991. Prosedur Penelitian Suatu Pendekatan Praktek. Jakarta : Rineka Cipta.

Arikunto, S. 1992. Prosedur Penelitian Praktis. Jakarta : Bina Aksara.

Anderson, Scarvia, B. et. Al. 1975. Encyclopaedia of Educational Evaluation. London : Josie-Bass.

Borg, Walter. R. and Meredith. D, Gall. 1983. Educational Research. New York : Long man.

Dash, N., \& Dash, M. (2007). Teaching English as an additional language. Atlantic Publishers \& Dist.

Fillmore, C. J. (1976). Frame semantics and the nature of language. Annals of the New York Academy of Sciences: Conference on the Origin and Development of Language and Speech, 280(1), 20-32.

Fishman, J. (1996). What Do You Lose When You Lose Your Language?.

Finochiaro, M. And Shako, S. 1960. Foreign Language Testing, A Practical Approach. New York : Regent Publishing.

Gay, L. R. 1987. Educational Research : Competencies for Analysis an Application. Ohio : Merrill Publishing Company.

Ground Lund, E. Norman. 1976. Measurement and Evaluation in Teaching. USA : University of Illinois.

Ground Lund, E. Norman. 1977. Constructing Achievement Test. New Jersey : Prentice Hall Inc.

Hawhee, D. (2006). Language as sensuous action: Sir Richard Paget, Kenneth Burke, and gesture-speech theory. Quarterly Journal of Speech, 92(4), 331-354.

Hewes, G. W., Andrew, R. J., Carini, L., Choe, H., Gardner, R. A., Kortlandt, A., Krantz, G. S., McBride, G., Nottebohm, F., \& Pfeiffer, J. (1973). Primate communication and the gestural origin of language [and comments and reply]. Current Anthropology, 14(1/2), 5-24.

Hornby, A. S. et. Al. 1984. Oxford Advanced Learner's Dictionary of Current English. Oxford : Oxford University Press.

Keith, Porter. 2003. Globalization: What is it? The Cold War Era and the Space Age have been replaced with the Era of Globalization for a definition from Keith Porter. Globalization.about.com. 08 January, 2004.

Lado, Robert, Ph. D. 1961. Language Testing. London : Long man Group Limited.

Lado, R. 1964. Linguistic Across Culture. Michigan : The University of Michigan Press.

Larsen-Freeman, D. (2012). Complex, dynamic systems: A new transdisciplinary theme for applied linguistics? Language Teaching, 45(2), 202-214.

Makoni, S., \& Mashiri, P. (2006). Critical historiography: Does language planning in Africa need a construct of language as part of its theoretical apparatus? In Disinventing and reconstituting languages (pp. 62-89). Multilingual Matters.

Plutchik, R. (2001). The nature of emotions: Human emotions have deep evolutionary roots, a fact that may explain their complexity and provide tools for clinical practice. American Scientist, 89(4), 344-350.

Oshima, A and Hogue, A. 1981. Writing Academic English. New York: Adison Wesley.

Ruiz, R. (1984). Orientations in language planning. NABE Journal, 8(2), 15-34.

Saeidi, M., \& Mazoochi, N. (2013). A comparative study on bilingual and monolingual Iranian EFL Learners' linguistic intelligence across genders. Life Science Journal, 10(6s). 
Stanley, A. J. And G. Martin. 1981. Evaluating Students Progress. Boston : Ally and Bacon.

Tinambunan, W. 1988. Evaluation of Student's Achievement. Jakarta : Departemen Pendidikan dan Kebudayaan.

Thomson, A. J. And Martinet, A. Y. 1976. A Practical English Grammar. Oxford University Press. Tuck man, B.W. 1978. Conducting Educational Research. New York: Harcourt Brace Jovanovich. Vockell, E. L. 1983. Education Research. New York : Mac Milan Publishing.

Gillette Wallace Jean and Temple Charles, 1988. Understanding Reading Problems. Harper Collin.

Wallace, M. J. 1998. Action Research for Language Teachers. Cambridge : Cambridge University Press.

Wren. 1990. High School English Grammar. Singapore : Oxford University Press

Wette, R. (2010). Evaluating student learning in a university-level EAP unit on writing using sources. Journal of Second Language Writing, 19(3), 158-177. 